\title{
Creating a 'monster': the National Youth Service pre-university training programme, student activism and the Kenyan state, 1978-90
}

\author{
Luke Melchiorre
}

\section{Introduction}

On Sunday 1 August 1982, non-commissioned air force officers initiated a coup d'état against the Kenyan government of Daniel arap Moi. They failed. Their attempt gave Moi the opportunity, and 'justification', to consolidate power and marginalize opponents (Branch 2011: 157; Throup 1987; Widner 1992). Subsequently, the Moi government did just that: it overhauled the leadership of the security forces; reconstituted the air force; and carried out a major crackdown at the University of Nairobi (Ajulu 2000: 146; Branch 2011: 157-9; Lynch 2011: 114; Throup 1987: 64-7; Throup and Hornsby 1998: 31-2; Widner 1992: 146).

This latter target of state repression would have come as no surprise to any observer with a passing knowledge of Kenyan politics during this period. By the late 1970s, the campuses of the University of Nairobi and its constituent, Kenyatta College, had been transformed into an important centre of national dissent. Considered apolitical, elites-in-waiting for much of the 1960s, from the early 1970s University of Nairobi students were increasingly portrayed by the state as violent and subversive. In the years immediately leading up to the coup attempt, the relationship between the government and the university's faculty and student body rapidly deteriorated, with the Moi regime banning the Nairobi University Student Organization (NUSO), de-registering the academic staff union and detaining student leaders and leftist lecturers, the latter of whom they accused of attempting to incite violence among their students against the government, in collaboration with unnamed foreign powers (Nderitu and Ndirangu 1982; Nderitu and Nyamu 1982; Musyoka and KNA 1982; Kuria 1982). ${ }^{1}$

When university students took to the streets en masse to celebrate the (premature) news of the fall of the Daniel arap Moi regime, their reputation as enemies of the state was cemented. In October of that year, less than three months after the failed coup, Moi announced the disbanding of the University of Nairobi, saying that his government 'want[ed] a new university ... with no prospect henceforth

Luke Melchiorre is an assistant professor in the Department of Political Science at Universidad de los Andes in Bogotá, Colombia. He received his $\mathrm{PhD}$ in political science from the University of Toronto in 2018. Email: jl.melchiorre@uniandes.edu.co

${ }^{1}$ See also 'Student grievances', The Weekly Review, 29 February 1980, p. 11; 'Magnificent five', The Weekly Review, 14 March 1980, pp. 12-13; 'Riot costs', The Weekly Review, 21 March 1980, p. 9; 'Invisible masters?', The Weekly Review, 11 July 1980, p. 13; 'Moi slams “Marxist” lecturers', Daily Nation, 25 May 1981, p. 1; 'GG blames outsiders', Daily Nation, 26 May 1981, p. 1; 'KANU resolves to contain agitation', The Weekly Review, 29 May 1981, p. 17; 'One step further', The Weekly Review, 29 May 1981, pp. 30-1; 'Detentions will continue - Moi', Daily Nation, 19 June 1982, p. 1.

(C) International African Institute 2019 
that it could lie in our midst as a source or instrument of destruction'. ${ }^{2}$ In that same speech, Moi singled out university students for criticism, arguing that the university had been 'brought into disrepute by a student body which proved itself pathetically vulnerable to the crudest stupidities of dialectical subversion'. ${ }^{3}$ These remarks suggested that Moi did not simply aspire to create a new university, but that he also desired to produce a new kind of university student: one who was obedient and loyal to his regime.

In May 1984, with this objective in mind, the government introduced the National Youth Service's pre-university training (NYSPUT) programme ${ }^{4}$ as part of a host of reforms designed to bring the university back under the government's control. ${ }^{5}$ The NYSPUT made it mandatory for students admitted to Kenyan universities to enter fourteen weeks of paramilitary training prior to their arrival on campus. Perhaps influenced by the perceived success of similar programmes in Tanzania (Bjerk 2015) and Zaire (Monaville 2012), the NYSPUT was officially conceived as a means of inculcating Kenya's prospective university students with the tenets of Moi's nyayo philosophy, which espoused Christian values of 'peace, love and understanding' and demanded obedience (Moi 1986: 120-1; Hornsby 2012: 401). It was hoped that the NYSPUT would facilitate the transformation of these students into 'disciplined' and 'responsible' citizens (Muya 1990), who would offer 'loyalty' to the Moi regime (Moi 1986: 121). The NYSPUT's introduction, therefore, needs to be understood within the broader context of the KANU government's attempt in the mid-1980s to 'elevate Moi's nyayo aphorisms into a political philosophy' that could lend the regime ideological legitimacy (Hornsby 2012: 401).

In practice, however, as this article will demonstrate, the scheme had unintended consequences: instead of fostering obedient and loyal university students who were ideologically committed to Moi's nyayo project, the programme served to further alienate these students from the ruling party, helping to politicize a significant

\footnotetext{
'`University set-up to be dissolved', The Weekly Review, 22 October 1982, p. 7.

${ }^{3}$ Ibid.

${ }^{4}$ It is important to distinguish the NYSPUT from Kenya's National Youth Service (NYS). The NYS was officially created in April 1963. The programme's recruitment was confined predominantly to single young men, preferably between the ages of sixteen and twenty-two, 'who [were] unemployed and [had] no immediate prospects for employment' (Kenyan National Archive (KNA) DC/KMG/2/27/399 (ADM/1/22) (21)). In exchange for providing their labour for national development projects, including road and dam construction, bush clearing and earthworks, these young recruits, the vast majority of whom had never attended secondary school, were provided not just with a small wage, food, clothing and shelter during their two years of service in the NYS but also received training in English, mathematics and civics from primary to post-KPE (Kenya Preliminary Examination) standard (Coe 1973: 31). It was hoped that these recruits' experiences at the NYS would better 'enable them to compete in the labour market' on completion of the programme (KNA COR/7/21). Given these criteria, university students were historically excluded from participation in the regular NYS programme. Even with the introduction of the NYSPUT in May 1984, prospective university students trained separately from regular NYS recruits in a special programme that had been designed specifically for them.

${ }^{5}$ These reforms included: dividing the University of Nairobi into five separate colleges (each headed by a state-appointed principal); appointing a growing number of university professors into the upper echelons of the national decision-making machinery and giving lecturers a raise in December 1984; and, perhaps most dramatically, amending the University Act in 1985, which shortened the term of the vice-chancellor from six years to three and enhanced the discretionary power of the president (and chancellor of the university) to appoint the leadership of the university administration.
} 
portion of them, who, by the time they arrived on campus, confronted the Moi state with some of its most defiant political challenges of this period.

To date, in spite of the publication of a number of studies documenting the history of student activism at the University of Nairobi during these crucial years (Amutabi 2002; Chege 2009; Kiai 1992; Klopp and Orina 2002; Mutunga and Kiai 1996; Savage and Taylor 1991; Omanga and arap Buigutt 2017), the experiences of student recruits at the NYSPUT and the programme's subsequent influence on the development of student activism at the University of Nairobi have remained largely undocumented. It is one of this article's central contentions that the NYSPUT played a crucial and hitherto unacknowledged role in shaping student activism at the University of Nairobi in a variety of ways during the latter half of the 1980s. First, for many student recruits, the experience of the NYSPUT was unfairly punitive and thus provided them with grievances around which to develop collective solidarity and through which a small but vocal core of students came to embrace oppositional politics. Second, the programme unwittingly provided students with the space and time to construct and nurture durable social bonds among themselves and to refine their political ideas, often in collaboration with one another. These bonds would be utilized once students arrived on campus and began to organize politically. Finally, during its afternoon lectures and question periods, it offered students an opportunity to confront and, on occasion, publicly challenge representatives of the Moi regime, often for the first time in their lives. These confrontations not only helped enhance the reputations of future student leaders among their peer group; they also exposed student recruits to the ideological shortcomings at the heart of Moi's nyayo political project. In this way, it can be said that, while the NYSPUT effectively served to discipline and punish the bodies of student recruits, it was ultimately guilty of disregarding their minds. ${ }^{6}$

In what follows, I examine the brief and turbulent experiment that was the NYSPUT. First, I situate the programme's origins and development within the broader historical context of student activism at the University of Nairobi and, more generally, within Kenya's incipient process of nation-state building. Next, relying on student recruits' own recollections, I describe their experiences of the camp. In the final section, I consider the implications of the NYSPUT for student activism at Nairobi, examining the activities of the programme's graduates once they arrived on campus, focusing on the period between September 1984 and August 1990. ${ }^{7}$

\section{'Crises of the moment': the historical origins of the NYSPUT}

In April 1975, Hilary Ng'weno, the editor of The Weekly Review, the most prominent news magazine in Kenya at the time, wrote about the KANU government's

\footnotetext{
${ }^{6}$ This idea came from a conversation that I had with Dr Sean Hawkins, following a presentation I gave on this research at New College, University of Toronto, in April 2015.

${ }^{7}$ This study is based on over fifty interviews with former University of Nairobi students, faculty members and administrators, as well as national politicians and members of Kenyan civil society from the 1970s and 1980s. Within this group, I interviewed fifteen NYSPUT graduates who attended the male NYSPUT training camp in Gilgil between 1984 and 1988. These interviews were conducted during three research trips to Kenya from September 2013 to December 2014.
} 
new plan to include university students in the national service scheme and foresaw many of the difficulties that would befall the programme. While he acknowledged the need for Kenya's ruling party to take the lead in organizing the scheme, he lamented the fact that 'there [was] no guarantee that it would be a policy which would be pursued and developed over a reasonable period of time', as KANU had a history of formulating 'policies only for the purposes of dealing with political crises of the moment. When these crises have passed the tendency is to forget the policies which were so vehemently pronounced and to let things take their usual apathetic course' (Ng'weno 1975).

Ng'weno's words provide an apt description of the history that was to unfold for the NYSPUT over the subsequent decade. While the scheme's architects initially emphasized the need to familiarize students with the realities of life in the countryside and the challenges of development in Kenya, in fact, as David Court (1980: 662) notes, proposals for the NYSPUT were continually 'characterized by apparent uncertainty about their precise purpose'. Indeed, the 'diversity of terms' that were used to justify the implementation of the proposed programme during this period, which included 'providing a foretaste of future employment, a way of meeting costs, a means to reduce student elitism through a period of rural living and so forth', reinforces this perception (ibid.).

In reality, the programme had more to do with addressing the emerging problem of student unrest than it did with any of the aforementioned justifications. It is important to note that the scheme was first concretely proposed only in April 1975,8 in response to a year-and-a-half period in which the university had been closed three times due to student protests, and just a month after the assassination of the popular politician and government critic J. M. Kariuki had produced unprecedented student riots on campus. ${ }^{9}$ From its beginnings, therefore, in the eyes of many university students and faculty, the programme was seen to be a punitive measure designed by the Kenyatta regime to 'cow Kariuki supporters [read: government critics] in the university' (Branch 2011: 119). While the October 1975 commencement date for the scheme was eventually postponed indefinitely without explanation, the perception of the programme as a 'punishment' for dissident students is one that would linger well into the $1980 \mathrm{~s}^{10}$

Over the next decade, until its eventual implementation in May 1984, calls to incorporate prospective or current university students into the NYS seemed to follow a specific pattern, ebbing and flowing in accordance with the state's

\footnotetext{
${ }^{8}$ The government did attempt to include university students in national development in 1966 with the ill-fated 'bonding' scheme, which was aimed to get students to serve in national departments for three years after their studies. The bonding scheme was never enforced, however, because the government realized that it could not offer sufficient jobs to suit all the types of graduates produced at the university.

${ }^{9}$ At this time, the Ministry of Education and Planning released an eleven-page document that outlined a plan for the NYSPUT that was intended to begin in October 1975. Under this proposed scheme, undergraduates at the University of Nairobi and Kenyatta College would be required to interrupt their studies to do a year-long stint on a 'National Service Scheme for University Students', where they would get an 'opportunity to gain practical experience in fields relevant to their studies and expose them thereby to developmental problems in [a] largely rural setting' ('At last the national service scheme is here', The Weekly Review, 7 April 1975, pp. 18-19).

${ }^{10}$ Ibid.; 'No punishment', The Weekly Review, 31 July 1981, p. 9; 'Questionable logic', The Weekly Review, 14 August 1981, p. 13.
} 
intermittent anxiety over student 'crises' at the university. When 'crises' on campus erupted, the government would publicly call for the implementation of the scheme, but such calls remained vague about specific details and would quickly fade into the background as soon as order appeared to be restored. Moreover, as time went by, rhetoric about the NYSPUT increasingly presented it as being less about 'provid[ing] students with the opportunity to gain practical experience in fields relevant to their studies' as it had initially been promoted, ${ }^{11}$ and more about instilling in students an ethos of discipline and obedience prior to their arrival on campus. ${ }^{12}$ To demonstrate this point, it is necessary to situate the origins and development of the NYSPUT within the broader context of events unfolding both within Kenya's national politics and at the university during this period.

\section{A brief history of student activism in Kenya, 1963-84}

The University of Nairobi, Kenya's oldest and most august institution of higher learning, is a relatively recent creation (Savage and Taylor 1991; Klopp and Orina 2002; Kamencu 2013). Officially founded in 1970, the university went through a number of prior incarnations, ${ }^{13}$ with its immediate predecessor, University College, Nairobi (UCN), becoming a constituent college of the University of East Africa in 1964 (Kamencu 2013: 15; Furley and Watson 1978).

As noted in the introduction to this special issue (Hodgkinson and Melchiorre 2019), in Kenya, as elsewhere in Africa, the pre-eminent importance of newly created universities to national projects of development and nation-state building was reflected in the fact that the President of the Republic was also made the chancellor of the national university (Balsvik 1998; Ade Ajayi et al. 1996; Young 1981). From the inception of UCN, the Kenyan state's relationship with its national university students was marked by deep ambivalence. On the one hand, the Kenyatta state relied on its university students to be the main source of a much-needed highlevel workforce, enabling it to Africanize its expanding bureaucracies. On the other hand, however, these same institutions of higher learning held out the possibility of cultivating 'a political counter elite' (Mamdani 2012: 86), providing as they did 'ideal spaces ... for [the] nurturing of alternative ideas that challenge[d] the hegemony of prevailing ideologies' (Mwangola 2007: 151). Moreover, 'university students' privileged status as elites-in-waiting, a by-product of their rarefied educational credentials, enhanced their national reputations and bestowed upon them the authority to exercise their voice and influence on the national political stage' (Melchiorre 2018: 7; see also Balsvik 1998; Waller 2006: 80). Not

\footnotetext{
11 'At last the national service scheme is here', The Weekly Review, 7 April 1975, p. 18.

${ }^{12} \mathrm{Or}$, as a report by the Kenya National Committee on Educational Objectives and Policies released in 1978 put it: '[Assisting] youth to grow into self-disciplined, self-respecting and lawabiding mature-minded ... people' ('Education report is all things to all men', The Weekly Review, 19 May 1978, pp. 3-10).

${ }^{13}$ The university was initially opened as the Royal Technical College of East Africa in 1956 (Luescher-Mamashela et al. 2016: 23). Following 1961, the Royal Technical College was rechristened the Royal College, Nairobi, first as a constituent college of the University of London, and later, in 1964, as a constituent college of the University of East Africa (Kamencu 2013: 15; Furley and Watson 1978).
} 
surprisingly, therefore, in the first decade of independence, African universities often came to be seen by the postcolonial state as a potential destabilizing site of politicization, just as likely to cultivate rivalries between its graduates and the state's new political leadership as they were to foster loyalty between them (Ivaska 2011: 125).

In contrast to many of their African counterparts, however, Kenyan university students in the 1960s remained seemingly 'immune to opposition politics' (Savage and Taylor 1991: 311), pursuing 'their studies with little active attention to the political world' (McKown 1975: 216). Beginning in the early 1970s, however, the national political role of students began to shift in accordance with changing international and domestic conditions. These included astronomical population growth, which reached a world-leading rate of 3.8 per cent by 1978, placing a heavy burden on Kenya's tertiary education system through dramatic increases in university enrolments (Branch 2011; Hornsby 2012; Amutabi 2003). ${ }^{14}$ This expansion of the student body increased the cost of the universities for the state and thus led to the implementation of a new loan scheme in July 1974, which outraged university students, replacing grants designed to cover their living costs with loans they were expected to pay back once employed (Klopp and Orina 2002: 49). In addition, university students were inspired to engage in leftist activism both by international developments on the continent, such as the Soweto Uprising against the apartheid government in South Africa in June 1976 (Omanga and arap Buigutt 2017: 580), and by the hiring of an influx of young, leftist African faculty at the University of Nairobi, who increasingly sought to engage their students in political discussion and activity. ${ }^{15}$ Finally, campus unrest was also driven by students' growing dissatisfaction over the country's authoritarian, political direction, especially in light of the banning of the opposition party, the Kenya People's Union (KPU), in 1969 and the assassinations of high-ranking and respected political figures such as Tom Mboya in that same year and Kariuki in 1975 (Tamarkin 1978: 316). All of these factors contributed to heightening levels of student protest at the University of Nairobi in the latter years of the Kenyatta regime.

Following Kenyatta's death in August 1978, Moi became the Kenyan Republic's second president and seemed initially committed to improving relations between the state and university students. In his first commencement address in November of that year, he implored University of Nairobi students 'to take a greater and more active interest in public matters than they had in the past' ${ }^{16}$ Immediately following this public pronouncement, Moi made a number of gestures that appeared to be trying to curry favour with students. In December 1978, he agreed to release all political detainees, including Ngugi wa Thiong'o, the author and beloved University of Nairobi professor. Later the following year, Moi invited student leaders of NUSO to State House and also

\footnotetext{
${ }^{14}$ The University of Nairobi's student population nearly doubled between 1970 and 1977, expanding from 2,800 to 5,400 (Hornsby 2012: 265). These changes led to students' privileges being curbed, more congested lecture theatres, overcrowded hostels and worsening sanitary conditions on campus (Amutabi 2002).

${ }^{15}$ 'Silent hallways', The Weekly Review, 22 May 1981, p. 13.

${ }^{16}$ 'Students warned', The Weekly Review, 26 October 1979, pp. 8-9.
} 
granted them permission for the first time to peacefully commemorate the loss of Kariuki on the anniversary of his death in March 1979. In addition, in April of that year, Moi even tried unsuccessfully to persuade the leadership of NUSO to set up a KANU branch on campus. ${ }^{17}$

This initial 'honeymoon period' between university students and the Moi state was to be brief and belied the depth of the political and economic challenges that Moi confronted as part of the complicated politics of presidential succession. Politically, as a member of a marginal ethnic group, the Kalenjin, Moi's presidential appointment had been actively opposed by much of Kenya's powerful Kikuyu elite (Nyong'o 1989; Throup 1987: 52-3; Throup and Hornsby 1998: 22). To consolidate his power, therefore, Moi had been required to realign the ethnic composition of the Kenyan state while at the same time attempting to ground his regime's legitimacy in alternative bases of popular support (Throup 1987). To compound his difficulties, these delicate political tasks were being undertaken in a moment of extreme economic turbulence, marked by rising inflation and unemployment and declining economic growth, which effectively narrowed the material bases of the state, making the dispensation of patronage, which had been crucial to the political stability of his predecessor's regime, difficult to sustain (Cooksey et al. 1995: 208-9; Branch 2011; Throup 1987: 57-64; Throup and Hornsby 1998: 23).

These political and economic difficulties were exacerbated by the fact that, during these years, the country's rapid population growth continued unabated, producing thousands of unemployed young Kenyans each year (Branch 2011: 137). By the 1980s, the contracting labour market meant that even university graduates were having trouble finding jobs (Cooksey et al. 1995: 208-9; Branch 2011). With the opening of three additional state-funded Kenyan universities in the 1980 s, ${ }^{18}$ doubling the number of university entrants by 1987, the standard of tertiary education also suffered (Branch 2011: 144-7). The combination of these factors had significant consequences for the relationship between the state and university students from the final months of the 1970s onwards, and there is no question that the spike in student strikes and demonstrations in subsequent years needs to be understood, at least in part, with reference to these changing demographic and material conditions (ibid.).

That said, by the end of the 1970s, the primary causes of this deteriorating relationship between the state and university students were political (Klopp and Orina 2002; Melchiorre 2018). Indeed, students' first protest against the Moi regime occurred only in October 1979, after Moi decided to ban progressive politicians Jaramogi Oginga Odinga, George Anyona and Achieng Oneko from running in that year's general election. It was in the aftermath of these events, between 1979 and the failed coup attempt in August 1982, that the University of Nairobi and Kenyatta College became, as The Weekly Review described it, 'like dormant volcanoes ready to erupt at any time', ${ }^{19}$ with these institutions being

\footnotetext{
${ }^{17}$ Ibid., pp. 7-8. Interview with Rumba Kinuthia, Nairobi, 13 June 2014.

${ }^{18}$ Kenyatta University College became an independent university in 1985. Moi University was established in Eldoret in 1984. Egerton University was transformed into a chartered public university in 1987 .

${ }^{19}$ 'New demo', The Weekly Review, 8 February 1980, p. 20.
} 
closed an unprecedented seven times on account of student disturbances ( Njau 1982). ${ }^{20}$ In addition, during this period, the Moi state decided to ban NUSO, de-register the Academic Staff Union, and arrest and detain a handful of student leaders and leftist lecturers.

By the early 1980s, in a context of escalating tension, Moi's rhetoric about the university became increasingly adversarial. In March 1980, at a speaking engagement at the Kiambu Institute of Science and Technology, after accusing lecturers and students of colluding with the intention of disrupting peace in the country, Moi warned that the government 'was prepared to lose a generation of [unruly] students', if that was what restoring order at the university required. ${ }^{21}$ Later that same month, Moi asserted that, in order to stop the 'spreading of the disease' of student strikes in secondary schools and at the university, his government would run background checks on prospective university students to ensure that they had not been involved in any strike activity. Moreover, Moi claimed that those who had participated in such activities may be rounded up and forced to participate in work camps in northern Kenya to remind those students of 'how hard life can be'. ${ }^{22}$ Having failed with the carrot, Moi now seemed willing to use the stick.

In July of the following year, just two months after the university's latest closure, discussions of the need for NYS training for university students once again returned to the national limelight, with the Ministry of Education informing all current Form Six students that they would be required to serve in the national service beginning in August 1982.23 Following the coup attempt at the beginning of that month, the introduction of the scheme was once again delayed, and it would be postponed on two more occasions, with the government's justification being, of all things, that after almost a decade of supposed planning, there was 'a lack of adequate preparation for the intake of the students' ${ }^{24}$ Finally, in May 1984, the first class of NYSPUT student recruits arrived at the NYS training camp in Gilgil.

Just as Ng'weno had warned, over the course of the decade, KANU continually oscillated on a set of clear guidelines about what the scheme would look like, who was to be included, how long the training would last, what year of students would be expected to attend, and what its official objectives would be. This inability to develop and refine a clear programme over the intervening years ${ }^{25}$ demonstrates the haphazard nature of the programme and fits neatly into a broader pattern of the first decade of Moi's educational policymaking. As with comparable educational policies implemented during this period, including the primary school

\footnotetext{
${ }^{20}$ 'Riots close campus again', The Weekly Review, 29 February 1980, pp. 9-10; 'Whose fault?', The Weekly Review, 7 March 1980, p. 11; 'No decision yet', The Weekly Review, 24 July 1981, p. 6; 'Go home', The Weekly Review, 12 June 1981, p. 11.

${ }^{21}$ 'Magnificent five', The Weekly Review, 14 March 1980, pp. 12-13.

${ }^{22}$ 'Riot costs', The Weekly Review, 21 March 1980, p. 9.

${ }^{23}$ 'Going back', The Weekly Review, 7 August 1981, p. 9; 'Questionable logic', The Weekly Review, 14 August 1981, p. 13.

${ }^{24}$ 'NYS training to start in '84', Daily Nation, 16 February 1984, p. 1.

${ }^{25}$ 'Questionable logic', The Weekly Review, 14 August 1981, p. 14; 'Going back', The Weekly Review, 7 August 1981, p. 9; 'Call-up', The Weekly Review, 27 January 1984, pp. 15-16; 'Waiting game', The Weekly Review, 24 February 1984, pp. 9-10.
} 
milk scheme of 1979 , the introduction of the 8-4-4 system in $1985,{ }^{26}$ and the decision to more than double university student intake in 1987, the NYSPUT was yet another example of the Moi regime pursuing dramatic educational reform in a poorly conceived manner, with both a brazen disregard for the advice of planners and professionals and a lack of consultation with the public (Cooksey et al. 1995: 207; Amutabi 2003). The consequences of this approach would be reflected in the way in which the NYSPUT programme was run during the latter half of the 1980s. It is to the student recruits' experiences of the camp that we now turn.

\section{Gilgil in reverse: student recollections of the NYSPUT}

At the first graduation ceremony of the NYSPUT in August 1984, Moi praised the programme's graduates for their ethos of discipline, hard work and self-control. At that same ceremony, Moi told the University of Nairobi's vice-chancellor, Dr Joseph Mungai, 'that he handed over the students to [Mungai] when they were sound, efficient and dedicated' and so if anything were to go wrong with them while on campus, the university administration, not the students themselves, would be to blame. ${ }^{27}$ As we shall see, Moi's confidence in the success of the programme would prove to be misplaced.

Officially, the NYSPUT, which initially consisted of three-and-a-half months of paramilitary training from the start of May until mid-August, was intended to instil in prospective university students feelings of 'national belonging', an 'appreciation of responsible and committed citizenship', and a sense of '[1]oyalty to the state' (Moi 1986: 121) prior to their entry on campus. Divided into a male course, which took place in Gilgil in Rift Valley, and a female course that took place in Naivasha, approximately 30 kilometres away, the male programme's official itinerary included a regimen of physical fitness exercises, foot drills, first aid training, camp craft and firefighting, with all student recruits being expected to attend a series of afternoon lectures on national development issues and strategies (Miguna 2012: 45). In its first year, the programme produced 1,820 graduates. By 1988, it had expanded to take in approximately 9,000 student recruits from all four of Kenya's public universities (Muya 1990). ${ }^{28}$

While the NYSPUT's high-minded objectives were often repeated in the Moi regime's public discussions about the programme, the president himself did not shy away from outlining perhaps a more candid justification for the scheme: namely, it was designed to deter future student unrest on campus, or, as he put

\footnotetext{
${ }^{26}$ The 8-4-4 system was a major educational reform introduced by the Moi regime in 1985, which aimed to create 'a more practically oriented curriculum'. Most notably, the reform meant that Kenyan students were now expected to take eight years of primary education, four years of secondary education and four years of tertiary education. This replaced the older 7-42-3 system, which consisted of seven years of primary school, four years of secondary school, two years of high school, and three to five years of university (Amutabi 2003: 136).

${ }^{27}$ 'Passing out', The Weekly Review, 17 August 1984, p. 9.

${ }^{28}$ With the double intake of students in 1987-88, the camp eventually had to be divided into two different annual sessions, one taking place prior to students' entry on campus and the second session commencing with a different set of first-year students after the completion of their first semester.
} 
it, to ensure that students were 'immunized against developing degenerate tendencies' (Moi 1986: 121), thus 'prepar[ing] [them] to go through the universities in a sensible and mature way' (ibid.). In short, at least according to Moi himself, the NYSPUT sought nothing less than the 'deliberate shaping of the ethos and character' of prospective Kenyan university students prior to their arrival on campus (ibid.).

In practice, however, some of the student recruits felt that the camp failed to achieve these objectives. Many had misgivings about the programme even before they arrived at the camp. This was primarily for two reasons. First, some wondered whether the paramilitary training provided at the NYSPUT would be appropriate for the kind of futures that higher education was expected to confer upon university students. As one student recruit, Aggrey Wasike, recalls, student recruits commonly wondered "why we ha[d] to go through the basic army training, when [as university students, we were] not going to need it in [our lives]'.29

Another fundamental concern about the programme held by some student recruits prior to their arrival at the camp was the belief that the NYSPUT was intended to be punitive in nature. Wasike, who attended the second session of the NYSPUT in 1987, recalls:

There was definitely a feeling [among student recruits] ... [of] what are we going to gain from [the NYSPUT]? They had us at the university first and then after that first semester we went to NYS[PUT]. We were okay that semester. We didn't do anything [wrong]. There wasn't any riot ... So there was the feeling [among student recruits] that [the NYSPUT] was a punishment and we were a group that didn't deserve to be punished. ${ }^{30}$

For many students, once they arrived at the camp, their initial experiences reiterated the sense that the NYSPUT was to be an unmerited punishment. One of the key sources of the student recruits' grievances related to the arduous conditions they had to endure at the camp. Student recruits with no military experience were expected to wake up at dawn, run through countless drills and military exercises, and participate in exhausting physical workouts, on very little sleep. Nights at the camp in Gilgil were often very cold and student recruits were given limited time to eat their food, they were expected to do all of their own washing, and they were forced to lodge in common living quarters.

To make matters worse, student recruits also recall being severely mistreated by some of the camp's afandes, the non-commissioned NYS officers who oversaw the student recruits' activities while at the camp. Many student recruits accuse these afandes of abusing their positions of authority and subjecting them to intimidation, verbal threats and even physical abuse. As one student recruit recalls, the afandes 'were happy to inflict physical damage on ... university students ... [they] were so devilish in terms of what they did to us that it was just a nightmare being at [the] NYS[PUT]'. ${ }^{31}$ A common reaction among student recruits to this mistreatment at the hands of the regular servicemen was anger. As former

\footnotetext{
${ }^{29}$ Interview with Aggrey Wasike via Skype, 26 August 2016.

${ }^{30} \mathrm{Ibid}$.

${ }^{31}$ Interview with Shadrock Nasong'o via telephone, 17 January 2017.
} 
student recruit George Gona recalls: 'We had accepted the fact that [the programme] was a pre-university entry requirement and we had to be there, but ... [the afandes] were humiliating us ... I mean we really wanted to burn the place down.' 32

At the root of many of these tensions between the student recruits and the afandes, at least from the perspective of many of those student recruits interviewed, was the educational gap that separated them from the non-commissioned officers. It is important to recall that the regular NYS was perceived by many to be a programme for the unemployed and undereducated. Indeed, it was certainly true that the vast majority of regular servicemen had never completed secondary school, let alone university. ${ }^{33}$ Student recruits contend that it was the afandes' 'envy' of their educational prospects that was at the heart of the mistreatment the former received from these regular servicemen. Indeed, afandes frequently made student recruits' educational achievements the source of ridicule within the camp. Upon entry into the NYSPUT, one student recruit recalls being told by an afande to put his 'Form Four certificate ... in [his] boot ... [and] forget [about] it', ${ }^{34}$ as such educational credentials had no significance within the space of the camp. ${ }^{35}$

In having to accept the abuse meted out by the afandes, many student recruits felt that they were 'being punished for passing [the university entrance] examination' 36 and they resented being treated like 'school dropouts' 37 by non-commissioned officers who had nowhere near their level of academic qualifications. $^{38}$ As former student recruit and Students Organization of Nairobi University (SONU) 1987 Secretary of Finance, Miguna Miguna, recalls:

This was the worst of it ... [these afandes] are subjecting you to this sort of dehumanizing treatment and these people did not finish ... elementary school. Cannot speak English ... All they know is shouting and for them they get satisfaction of [sic] having to do this to someone who presumably performed better than them and progressed to A-levels. ${ }^{39}$

For some recruits, the poor treatment that they received at the hands of the afandes raised more profound questions about the government that had organized the camp and sanctioned its conditions. As Wasike recalls: 'How the afandes treat[ed] [student recruits] ... you just ask [yourself] what is the point of all of this? Why is the government making you do that? [The NYSPUT] didn't make [student recruits] more disciplined. It was actually the opposite ... it strengthened [their] anti-government stance. ${ }^{40}$

\footnotetext{
${ }^{32}$ Interview with George Gona, Nairobi, 1 July 2014.

${ }^{33}$ Richard Coe (1973) found that, from June 1965 to December 1966, 87.7 per cent of NYS recruits had not attended secondary school, with 16.6 per cent being illiterate.

${ }^{34}$ Interview with George Gona, Nairobi, 1 July 2014.

${ }^{35}$ Some student recruits would return this abuse, telling the afandes that 'this is the only place that [the government] would accept you. Look what you have around here, it is nothing' (interview with Aggrey Wasike, Toronto, 28 August 2016).

${ }^{36}$ Interview with Miguna Miguna, Toronto, 29 July 2014.

${ }^{37}$ Interview with George Gona, Nairobi, 1 July 2014.

${ }^{38}$ 'Clashes between varsity students and regular servicemen', The Weekly Review, 21 October 1988 , p. 18.

${ }^{39}$ Interview with Miguna Miguna, Toronto, 29 July 2014.

${ }^{40}$ Interview with Aggrey Wasike via Skype, 28 August 2016.
} 
It is important to note that these tensions occasionally resulted in violent clashes breaking out between student recruits and their non-commissioned officers. For example, former student recruit and eventual Kenyan parliamentarian T. J. Kajwang recalls that 'sporadic mutinies' carried out by student recruits against the regular servicemen 'happened all the time' at the camp during his spell there in $1988 .{ }^{41}$ The most famous example of such a clash took place in October of that year. National news media reported that the Kenya Police AntiStock Theft Unit and the General Service Unit (GSU) were called in to the Gilgil training camp to break up an altercation between student recruits and regular servicemen. This violent confrontation resulted in several people being seriously injured and the expulsion of all student recruits from the training programme. Adding to the state's embarrassment over the incident was the fact that the rioting student recruits in question were scheduled to represent all university students at the week-long, ten-year anniversary celebrations of the nyayo era later that month. ${ }^{42}$

The University of Nairobi's vice-chancellor, Philip Mbithi, suggested that the riot had begun when some drunken freshmen's forcible demand to visit their female counterparts at the Gilgil camp was declined by NYS regular servicemen. Student recruits themselves argued that the clashes were in fact related to the 'animosity between the NYS servicemen and the freshmen [which] had been building up for weeks'. ${ }^{43}$ Moreover, they complained that the camp's 'near inhuman [sic] conditions' with its 'long queues for food during meal times and the insufficient accommodation facilities that could not cater for all the 7,000 students' had also played a part in spurring on students' ire. ${ }^{44}$

The punitive nature of the camp produced a number of unintended consequences. First, many student recruits attested to the fact that the military training at the camp had served to 'harden' them, making them physically stronger and less reluctant to confront the police and other authorities. As NYS pre-university training graduate and former SONU chairman Omondi Alayoo recalls, the NYSPUT made student recruits 'more assertive', as they realized that 'the disciplined forces were not any different from us'. ${ }^{45}$ As such, when these student recruits arrived on campus, they felt they could '[g]o head to head with [the authorities]'.46

As we shall see in the next section, the NYSPUT graduates' willingness to fight back against the police during protests at the university in November 1987 and the NYSPUT riot in Gilgil in October 1988 attest to this 'hardening' and the newfound bravery and assertiveness that NYSPUT student recruits acquired during their experiences at the camp. As one student recruit recalls:

[After the NYSPUT] you felt like you can combat even the police ... how the students fought back when [student leaders] were arrested [in November 1987] had a lot to do

\footnotetext{
${ }^{41}$ Interview with T. J. Kajwang, Continental House, Nairobi, 17 July 2014.

42، Clashes between varsity students and regular servicemen', The Weekly Review, 21 October 1988, pp. 17-19; 'You've disappointed me', Daily Nation, 22 October 1988, p. 1.

${ }^{43}$ Ibid.

${ }^{44}$ Ibid.

${ }^{45}$ Interview with Omondi Alayoo, Nairobi, 28 May 2014.

${ }^{46}$ Ibid.
} 
with the training they had been through in NYS[PUT], because when you are in NYS[PUT] you are called a soldier ... we used to joke [that] what [the NYSPUT] ha[d] managed to create is revolutionary soldiers ... against the [Kenyan] state. ${ }^{47}$

In addition, the widespread sense of grievance on the part of student recruits in the programme also provided an important basis for solidarity among them to blossom. This was compounded by the fact that the programme had given student recruits an unprecedented opportunity to congregate with each other and develop social bonds among themselves over an extended period of time before entering university. As one student recruit recalls, at the NYSPUT, student recruits had 'a lot of time on [their] hands' and were given the 'opportunity' to 'interact' and 'actually share knowledge in an atmosphere where there is no pressure for reading, [or] for passing exams' ${ }^{48}$ The pre-university training programme, therefore, proved to be for some student recruits not only a 'good way to socialize before getting to campus'49 but also a space in which student recruits were able to develop durable social networks that served them well when it came to political organizing once they arrived at university. Indeed, a common sight at the University of Nairobi throughout the latter half of the 1980s was former NYSPUT student recruits spontaneously running military marches learned at the programme. ${ }^{50}$

Moreover, for some, this time also gave them a chance to refine their political ideas in collaboration with their colleagues. As former student recruit and legendary student leader Wafula Buke recalls, the NYSPUT camp provided him and other former student recruits with 'an opportunity to establish common ideological ground for future cooperation' (Buke n.d.). As such, in his estimation, 'the outcome [of the NYSPUT] was [to foster] a more critical student mass than [had existed] before'. ${ }^{51}$ Miguna concurs:

I went to the University of Nairobi. [At the NYSPUT] I met students at Kenyatta [University]. I met students at Moi [University]. I met students at Egerton [University]. Students that I would never have met in a normal school year and we were able to connect. We were able to identify strong people, weak people, how to mobilize ... It later on became a very good experience for some of us, who were interested in mobilizing for [national political] change. ${ }^{52}$

A third and final important by-product of the programme related to the political training that was on offer at the NYSPUT. As noted, the NYS pre-university training camp included 'a large number of talks and lectures' that were designed to familiarize students with KANU's vision for national development (Moi 1986: 120). During these talks, national politicians, civil servants and party officials typically discussed topics ranging from the merits of Kenya's new educational policy,

\footnotetext{
${ }^{47}$ Interview with Kaberere Njenga, Nairobi, 26 May 2014.

${ }^{48}$ Interview with Omondi Alayoo, Nairobi, 28 May 2014.

${ }^{49}$ Interview with Ken Ouko, Nairobi, 11 July 2014; interview with Godfrey Muriuki, Nairobi, 23 July 2014.

${ }^{50}$ Ibid.

${ }^{51}$ Interview with Wafula Buke, Orange House, Nairobi, 21 May 2014.

${ }^{52}$ Interview with Miguna Miguna, Toronto, 29 July 2014.
} 
8-4-4, to the tenets of Moi's nyayo philosophy, to the political history of the ruling party. Yet, as Miguna recounts in his memoir, these 'political sermons' were often little more than '[KANU] and government bigwigs from Nairobi ... shout[ing] themselves hoarse about patriotism, Nyayo philosophy and the need for respect for elders' (2012: 46). While some student recruits recall using these afternoons as a time to catch up on much-needed sleep, ${ }^{53}$ for others these lectures exposed them to the ideological bankruptcy at the heart of the ruling party and the project of the NYSPUT itself, and thus solidified their commitment to oppositional politics. As Buke recalls:

The manner in which the [lecturers] were packaging their stuff [during the afternoon lectures] ... was so bad that we are now poking holes [in it] ... So actually it was from that youth service that I realized no ... if a professor [giving the lecture at the NYSPUT] can reason like this, there is a major problem in this country. I was going to [major in] education. I decided to change and go do political science. So that I can understand what politics makes a professor ... not reason well ... So I shifted from [Kenyatta] College to Nairobi University purely because of the realization that this country has a crisis and that crisis is political. ${ }^{54}$

The question periods that followed these lectures also afforded student recruits the novel opportunity to confront representatives of their government in a public forum, often for the first time in their lives. As one student recruit remembers, 'Students would use [the lectures] to express their displeasure ... and become confrontational [with the authorities]. ${ }^{\prime 5}$ As a result, these question periods sometimes became the site of tense contestation between government representatives or NYS administrators and the student recruits themselves. ${ }^{56}$ Following such challenges, student recruits recall having their microphones taken away by the authorities in mid-sentence, or subsequently being asked to sign statements containing their public critiques of the government or the speaker in question, ${ }^{57}$ presumably so that the government could have a record of them. In one rare case, a student recruit even reports being detained within the camp following his challenge of a powerful government official during one of these lectures. ${ }^{58}$

These actions on the part of the organizers of the NYSPUT lend credence to Dr Peter Anyang Nyong'o's assertion that the programme was devised to better enable the Moi regime to get insights into "who students were [prior to their arrival on campus] ... so that [the state could] follow them after NYS[PUT]' and be better able to 'track ... and control them'. ${ }^{59}$ As Nyong'o suggests, the NYSPUT was designed as a mechanism of surveillance, enabling the government to get a sense of who the 'troublemakers' were within the incoming classes of university students prior to their arrival on campus. That said, by publicly

\footnotetext{
${ }^{53}$ Interview with Aggrey Wasike via Skype, 29 August 2016; interview with Kiama Gitahi, Nairobi, 17 July 2014.

${ }^{54}$ Interview with Wafula Buke, Nairobi, 21 May 2014.

${ }^{55}$ Interview with Aggrey Wasike via Skype, 28 August 2016.

${ }^{56}$ See Miguna (2012). Interview with Wafula Buke, Nairobi, 21 May 2014; interview with Aggrey Wasike via Skype, 28 August 2016; interview with Ambrose Weda, Nairobi, 18 June 2014.

${ }_{58}$ Interview with Wafula Buke, Nairobi, 21 May 2014.

${ }^{58}$ Interview with Ambrose Weda, Nairobi, 18 June 2014.

${ }^{59}$ Interview with Peter Anyang Nyong'o, KICC, Nairobi, 10 June 2014.
} 
challenging the regime during those afternoon lectures, some student recruits were also able to get the attention and admiration of their peers, establishing their reputations as firebrands and political leaders. Some of these men would rise to political prominence within student politics, and also, in some cases, they would later become noted public figures at the national level, like Buke and Miguna. As such, the experience of the NYSPUT helped students establish a 'pecking order' that enabled them to know "who was who and who they could follow [politically, once they arrived at the university]'. ${ }^{60}$

Far from succeeding in consolidating prospective university students' loyalty to the state and commitment to the political project of Moi and KANU, therefore, by the end of the camp the opposite had been achieved: many students found that the programme was not designed to rear them as leaders of tomorrow or provide them with a useful political education, but rather to 'dehumanize [them], to break [their] spirit, to make [them] feel that [they] were nothing'. ${ }^{61}$

Aside from simply angering students or turning them against the regime, student recruits' experiences of the NYSPUT also provided them with opportunities that they may not have had if the camp had not existed. As Miguna notes:

What [the experience of the NYSPUT] also did, which would not have been achieved if they had not put us in one place, is that it brought unity among students, from the rich to the poor, [who realized] we now had a common enemy to fight ... Moi and his system. ${ }^{62}$

For many former student recruits, therefore, the experience of the NYSPUT left them feeling more alienated from, and antagonistic towards, the state and the ruling party under Moi than they had been before. Moreover, for some, the experience of the NYSPUT steeled their resolve to fight not just the university administration, but also the regime. As Kajwang recalls, the camp 'had aroused in [him] the struggle to rebel against oppressive authority'. ${ }^{63}$

\section{'Bloody Sunday' and the political life of NYSPUT graduates on campus, 1984-87}

By the mid-1980s, the Moi government's brutal authoritarianism had reached unprecedented heights, utilizing repressive tactics which evoked the colonial era, including torture, arbitrary arrest, detention without trial and police brutality (Adar 2000; Ajulu 2000: 141). By the mid-1980s, as Hornsby (2012: 398) notes, '[All] opposition to the government was treated as subversion, and the sole criterion for political success became loyalty to the president. ${ }^{94}$ During this period,

\footnotetext{
${ }^{60}$ Interview with Omondi Alayoo, Nairobi, 28 May 2014.

${ }^{61}$ Interview with Miguna Miguna, Toronto, 29 July 2014.

${ }^{62}$ Ibid.

${ }^{63}$ Interview with T. J. Kajwang, Continental House, Nairobi, 17 July 2014.

${ }^{64}$ Much has been made of the power Moi invested in KANU and the efforts he exerted to reinvigorate the ruling party during this period (Widner 1992). While it is important to recognize, as Gabrielle Lynch notes, that Moi carried out recruitment drives that increased party membership to 8 million by 1988 and while he did use KANU 'to discipline individuals and control political space ... [the party] never served as the key means of mobilizing support or of monitoring
} 
freedom of the press was further constrained, intellectuals continued to be harassed and jailed, and the government initiated a major crackdown on Kenya's main underground socialist movement, Mwakenya, in 1986. Under such conditions, the university became 'one of the only remaining spaces where criticism of the government could be articulated' (Mwangola 2007: 152), and Moi, through the implementation of his post-coup reforms, was eager to eliminate that autonomy.

In late 1984, as the first batch of NYSPUT graduates began to acclimatize to life at the university, it appeared that these post-coup reforms were working. Describing the atmosphere on campus as late as January 1985, The Weekly Review noted that 'unrest at the University [seemed] like a thing of the past', and that a 'new spirit of co-operation [had] prevailed between the university and the authorities for almost two years [since the coup]' ${ }^{65}$ During that period, Moi had made a series of conciliatory gestures towards students: releasing, in February 1983, sixty-one student detainees; inviting student representatives to accompany him on trips to China, India and Tanzania; making periodic visits to campus to share tea with students at the university sports ground; and requesting the company of delegations of students to join him at State House. ${ }^{66} \mathrm{It}$ is precisely for these reasons that the eruption of protest on campus in February 1985, which resulted in the death of a student, came as a double shock to the regime. Not only had student unrest unexpectedly returned to the university, but also it soon became clear that the much-praised NYSPUT graduates had played an important role in these disturbances.

The trouble began on the morning of 5 February 1985, when three University of Nairobi students were expelled and another five had their scholarships revoked, although no official explanation was provided by the state for these punitive measures (Ndirangu and Njihia 1985). ${ }^{67}$ Included in this group was the popular graduate student and former SONU chairman Mwandawiro Mghanga. In the aftermath of the news, students peacefully gathered at the Great Court daily, boycotting lectures, seeking a High Court injunction against the expulsions, and demanding an official explanation for the government's decision against the censured students (Osiemo 1985; Ndirangu and Njihia 1985).

These tensions resulted in violence on 10 February, a day that would come to be known as 'Bloody Sunday', when a non-denominational prayer meeting organized by students was disrupted by plainclothes policemen and members of the GSU, who proceeded to open fire with their tear gas canisters. The assault by the security forces, undertaken in the presence of the University of Nairobi's vice-chancellor, Joseph Mungai, and the resulting pandemonium left sixty-five

and controlling the opposition, neither did it dominate the administration nor propagate a distinctive single-party platform' (Lynch 2011: 117-18; Hyden 1994). Instead, the 'central locus of state power' remained with the Office of the President (Lynch 2011: 117-18).

${ }^{65}$ Quoted in 'Nairobi University closes once again', The Weekly Review, 15 February 1985, p. 3; 'On the right road', The Weekly Review, 29 June 1984, p. 19; 'New dialogue', The Weekly Review, 9 March 1984, p. 15.

${ }^{66}$ 'Freed', Daily Nation, 23 February 1983, p. 1; 'New dialogue', The Weekly Review, 9 March 1984, p. 15.

${ }^{67}$ 'Trouble at university', The Standard, 7 February 1985, p. 1; 'Varsity students boycott lectures', Daily Nation, 7 February 1985, p. 1. 
students and thirty-two policemen injured, saw Mghanga 'taken away by four policemen' (Mulaki et al. 1985: back page), and resulted in the death of a twenty-three-year-old University of Nairobi student, Jacob Okhalo Wandera. ${ }^{68}$

While there is much disagreement about the specifics of the events that transpired that day, the explanation for the security forces' decision to attack university students peacefully meeting on campus is less contentious. Numerous eyewitnesses and participants assert that the NYSPUT graduates were planning to perform a guard of honour in full NYSPUT uniform following the prayer meeting. Whereas normally such a ceremony would be presided over by the president or by high-ranking military or government officials, former student recruits had decided that they wanted Mghanga himself to inspect it. By performing such a ceremony, and by having it presided over by a recently expelled student leader, the NYSPUT graduates intended to symbolically challenge the legitimacy of the Moi regime and to assert the autonomy of the student body at the university. ${ }^{69}$ As one former SONU chairman and NYSPUT graduate recalls, for the students, 'the symbolism [of having Mghanga lead the guard of honour] was ... that the university was a state unto itself'. ${ }^{70}$

In the aftermath of the event, The Weekly Review reported that 'only a handful of students turned up in NYS uniform, and up until the police moved in, no mention was made of the guard of honour'. ${ }^{71}$ Still, in a statement from the Office of the President in the days following the incident, the government confirmed the story, contending that the police actions were warranted because university students were trying to 'establish their own authority within the University', as first-year undergraduates were said to have intended to 'parade, in National Youth Service uniforms for the purpose of staging a guard of honour to be inspected by the self-imposed student leader, Julius Mwandawiro [Mghanga]' (Ndirangu 1985). ${ }^{72}$ In the aftermath of Bloody Sunday, the university was closed once again and nineteen students, including Mghanga, were arrested (ibid.; Kuria 1985). ${ }^{73}$

This, however, did not succeed in intimidating students into silence. Just over a month after Bloody Sunday, a new scandal emerged on campus, which once again grabbed national headlines and centred on graduates of the NYSPUT and their uniforms. In late March of that year, in an attempt to limit future embarrassment, the government released a circular ordering students to return all NYSPUT

\footnotetext{
68'Students defy official order', Daily Nation, 12 February 1985: 'Students dispersed by police', The Standard, 11 February 1985, p. 1; 'University campus closed', The Standard, 13 February 1985 , p. 1, 3. The government's claim that students had been throwing stones was rejected by newsmen at the meeting, Mungai and other eyewitnesses. Wandera, the brother of Kenya's then Assistant Secretary of Foreign Affairs, died at Choromo Hospital at 3 a.m. on 11 February 1985 following injuries sustained during the clash with police ('Students defy official order', Daily Nation, 12 February 1985, back page). He was the first student to be killed in such circumstances in the history of the University of Nairobi.

${ }^{69}$ Interview with Mwandawiro Mghanga, Nairobi, 19 May 2014; interview with Nduma Nderi, Upper Hill, Nairobi, 27 May 2014; interview with Omondi Alayoo, Nairobi, 28 May 2014.

${ }^{70}$ Interview with Omondi Alayoo, Nairobi, 28 May 2014.

${ }^{71}$ 'Man on a tightrope', The Weekly Review, 19 April 1985, p. 6.

${ }^{72}$ 'University campus closed', The Standard, 13 February 1985, p. 1; 'Man on a tightrope', The Weekly Review, 19 April 1985, pp. 6-7.

${ }^{73}$ 'Court jails one, fines three students', The Weekly Review, 12 April 1985, p. 4.
} 
uniforms prior to being granted readmission to the university (Mwangi and Gicheru 1985). These same uniforms had only eight months earlier been 'given to students as a token of appreciation for their performance during the [NYSPUT] service'. ${ }^{74}$ Instead of returning the uniforms as ordered, former NYSPUT graduates decided to publicly burn them at the main gate of Kenyatta College on the morning of 21 March 1985 (Ong'iyo and Musyoka 1985). This followed an evening when these same former student recruits 'marched around campus in similar drills they had learned at the [NYSPUT] scheme' (ibid.).

The combination of the proposed guard of honour and the student recruits' public burning of their NYSPUT uniforms provided the first pieces of concrete evidence that the scheme was becoming counterproductive from the perspective of the Moi regime. Instead of fostering discipline and obedience in its graduates, the NYSPUT seemed to be having the opposite effect. Mghanga himself acknowledges this:

The [NYSPUT] students themselves took [the] initiative [to plan the guard of honour] ... [w]ithout my knowledge ... you can see that the [NYSPUT] really radicalized the students, instead of intimidating [them] ... [In the aftermath of Bloody Sunday, Moi] thought now the [NYSPUT] is dangerous. ${ }^{75}$

A number of graduates whom I interviewed from the programme's first year agree with Mghanga's assessment of the emboldening impact that the NYSPUT had on them. Nduma Nderi, a first-year NYSPUT recruit and eventual SONU chairman, contends that, after the NYSPUT, student recruits took the lead in planning the guard of honour because they 'perceived [them]selves to be leaders of the pack, having come from disciplined training'. ${ }^{76}$ Alayoo goes further:

[The NYSPUT was a space] where you are radicalized ... By the time that you were coming out of NYS[PUT] ... [you] know who the enemy is [i.e. the Kenyan state] ... [After Bloody Sunday, Moi] realized he had a monster on his hands. ${ }^{77}$

Following these events, however, university students' attitudes on campus towards activism seemed to become split according to their year. Upper-year students, who had experienced the NYSPUT but, in some cases, had had their education delayed by up to two or three years on account of the frequent university closures, were eager to graduate and for many of them 'activist fatigue' had set in. ${ }^{78}$ As 1985 SONU chairman Nderi recalls:

We lost two years after the coup and then we almost lost another whole year [after Bloody Sunday], so when I became chairman [in 1986], there was a clamour for peace and students wanted to leave ... A lot of [upper-year students] became apolitical, not because

\footnotetext{
74، Man on a tightrope', The Weekly Review, 19 April 1985, pp. 6-7.

${ }^{75}$ Interview with Mwandawiro Mghanga, Nairobi, 19 May 2014.

${ }^{76}$ Interview with Nduma Nderi, Nairobi, 27 May 2014.

${ }^{77}$ Interview with Omondi Alayoo, Nairobi, 28 May 2014.

${ }^{78}$ Interview with Nduma Nderi, Nairobi, 27 May 2014.
} 
they had no opinion [or because] they were for the establishment, but there was [a] realization that we needed to get out of the university. ${ }^{79}$

As Mwongela Kamencu (2013: 98) notes, in stark contrast, incoming first-year students, led by Buke, were distinguished from the upper years by the fact that 'unlike their predecessors ... [these] students had not been directly affected by the attempted coup nor ... by the closure of the University in the aftermath of Bloody Sunday'. As such, they did not feel the same urgency to complete their degrees that the upper-year students did. For these lower-year students, the main challenge was, in the words of Buke, to 'sustain the radicalism that existed before us' ${ }^{80}$ Within their first year, Buke and his allies organized a demonstration against the American bombing of Libya, which garnered national press coverage. Buke credits the NYSPUT for the political intensity of his first year at the university:

I can imagine if you just came [to the university] straight from home ... you can take a little while before you make your way around. But remember I organized a demo in [the] first year. I had never been in Nairobi since I was born. The first time I am landing in Nairobi [University] ... I am conscious and confident enough to organize a demo in solidarity with another country out there [Libya]. The reason [was because] my foreplay had been done in the [NYSPUT] ${ }^{81}$

Following the events of early 1985, two moderate candidates, Nderi and Maina Kiranga, perhaps with the help of the university administration (Klopp and Orina 2002), led SONU as chairmen in 1985 and $1986 .{ }^{82}$ Still, in the following year, Buke won the SONU chair in a historic landslide, garnering 3,030 votes (out of approximately 4,000). ${ }^{83}$ The SONU leadership team of that year featured a number of radical student leaders who had been through the NYSPUT, including their chair (Buke), secretary-general (Kaberere Njenga), vice-chairman (Munoru Nderi) and secretary of finance (Miguna). Almost immediately, at their swearing-in ceremony, just days after Moi had announced a Sh300 increase in government-provided student allowances, ${ }^{84}$ the SONU leadership forwarded a number of militant proposals, which explicitly challenged the wishes of the state. First, SONU called for the disbanding of ethnic organizations or district associations on campus, which they argued exacerbated ethnic tensions that led to student disunity. Second, SONU called for a ban on all government-funded student trips abroad, in an effort to prohibit one of Moi's more high-profile methods of dispensing patronage to the student body. Third, SONU called for students to play a more active role in national political debates. ${ }^{85}$

On 15 November, just two days after the kamukunji when student leaders made these defiant public declarations, seven of SONU's most prominent leaders were

\footnotetext{
${ }^{79}$ Ibid.

${ }^{80}$ Interview with Wafula Buke, Nairobi, 21 May 2014.

${ }^{81}$ Ibid.

${ }^{82}$ Nderi's victory over Buke was, for some, highly contentious and remains disputed.

${ }^{83}$ 'A predictable pattern', The Weekly Review, 17 November 1987, p. 18.

${ }^{84}$ 'Moi raises varsity student allowance', Daily Nation, 12 November 1987, p. 1.

${ }^{85}$ Ibid.
} 
rounded up and arrested in an early-morning campus raid by the security forces (Musyoka and Nyamora 1987; Mwangi 1987). ${ }^{86}$ In response, university students, in the absence of their union's leadership, spontaneously 'became riotous, barricading public roads and refusing to attend classes' ${ }^{87}$ In the 'ensuing battles between students and the police ... one student [was] shot in the shoulder, many others injured and 40 arrested'. ${ }^{88}$ Over the coming weeks, the government responded by again closing the university, expelling forty-three students (including the six student leaders), de-registering the students' organization and threatening to introduce fees for students attending the university (Njau et al. 1987: 1; Muya 1987). ${ }^{89}$ Buke would remain in prison for the next five years.

In many ways, this unfortunate incident followed a 'predictable pattern' in the ongoing struggle between the state and university students in Kenya during the 1980s. ${ }^{90}$ Indeed, with approximately twenty closures between 1970 and 1990, the University of Nairobi had one of the highest rates - if not the highest - of campus closures in all of Africa during that twenty-year period (Balsvik 1998: 305). Still, given that for much of the 1970s and 1980s the campus of Nairobi University existed, as Mshai Mwangola (2007: 152) notes, as a 'location of complicated political contest pitting pro-government positions against pro-opposition ones', the widespread popularity of the newly elected SONU 1987 leadership among their student colleagues, in conjunction with that leadership's explicitly progressive political agenda, demonstrated the unprecedented sense of unity and anti-regime sentiment that had come to mark Kenya's young generation of university students by this time. Against their best-laid plans, the Moi regime's decision to implement the NYSPUT, designed to rein in the dissidence of these very students, had produced the opposite effect, playing a significant role in fostering the creation of an unprecedentedly united, militant and mobilized student mass that was unafraid to publicly challenge the Moi regime.

\section{Conclusion}

On 25 August 1990, just over six years after the graduation ceremony of the first NYSPUT camp, the government announced the suspension of the programme. The official justification was that the double intake of university students would have required the programme to admit three times the number of students it had trained the previous year, and it was thought that this was not financially feasible (Muya 1990). Still, what was beyond dispute by this time was that the scheme, marred by the memories of Bloody Sunday, the Kenyatta University NYSPUT uniform burning incident of March 1985, and the October 1988 student riot at

\footnotetext{
${ }^{86}$ These were the chairman Robert Wafula Buke, vice-chairman Munoru Nderi, finance secretary Miguna Miguna, foreign secretary Mbeji Mnameza, secretary-general Kaberere Njenga, academic secretary Amuomo Ngala, and vice secretary-general Margaret Ben.

${ }^{87}$ 'A predictable pattern', The Weekly Review, 17 November 1987, p. 18.

${ }^{88}$ Ibid.

${ }^{89}$ 'Students may pay their own fees', Daily Nation, 17 November 1987, p. 1.

${ }^{90} \mathrm{Ibid}$.
} 
the ten-year nyayo anniversary celebrations in Gilgil, had not achieved the objectives that it had set out to meet.

Indeed, as this article has demonstrated, far from transforming future university students into compliant, pro-government young citizens loyal to the ruling party, the programme had produced the opposite effect: helping create a student body that was more united and antagonistic towards the state, and ready to combat it directly by force, if necessary. A number of SONU's most prominent student leaders of this period, some of whom played a key role recently as primary practitioners of Raila Odinga's 'People's President' campaign ${ }^{91}$ (Amuke 2018), agree that the NYSPUT served as a formative space in which student activists were radicalized and emboldened, enabling them both to develop a 'pecking order' and to establish durable, political networks that flourished once they arrived on campus.

Ultimately, the Moi regime's failed experiment with the NYSPUT in the last half of the 1980s directs us to reflect on the ways in which states attempt to channel, supervise, discipline and punish their populations of young people in order to compel them to serve the state's top-down objectives (Burgess and Burton 2010: 12; Honwana and De Boeck 2005; Comaroff and Comaroff 2005; Waller 2006). The experience of the NYSPUT reminds us that often these state projects, which are designed to make a population legible or compliant to a central authority, produce outcomes that are at odds with these states' desired objectives (Scott 1998).

\section{Acknowledgements}

I want to thank everyone in Kenya who helped me with this project: friends, colleagues and interviewees. With special thanks to Mwongela Kamencu, for his insight and research assistance, Onyango Oloo, for providing initial contacts, Willy Mutunga, for his generosity and encouragement, Rose Akinyi, for her friendship and research assistance, and Wambui Mwangi, for her warm hospitality in Nairobi and her generous guidance and support. In addition, I would also like to thank my doctoral supervisor, Dickson Eyoh, Courtney Jung, Antoinette Handley, David M. Anderson, Jacob Rasmussen, Wangui Kimari, Sean Hawkins, Noaman Ali, Kate Korycki, Melissa Levin and Maria Fernanda Moreno for agreeing to read earlier drafts of this article and for giving me such useful feedback. Finally, I would also like to thank all of those who attended my talks on earlier versions of this article and related papers at the British Institute in Eastern Africa (BIEA) in Nairobi in November 2014 and at the Senior Fellowship Luncheon Series at New College, University of Toronto in April 2015, and all those who participated in the 'Student Activism Reconsidered' workshop in Oxford in July 2016.

\footnotetext{
${ }^{91}$ Three of the former NYSPUT student recruits interviewed for this study were influential in Raila Odinga's 'People's President' campaign in 2018. Two of them received international attention for their involvement and eventual arrest. Most notably, Miguna Miguna was arrested and later deported by the Kenyan government in February 2018 for his role in Odinga's swearing-in ceremony as the 'People's President' at Uhuru Park in Nairobi in January 2018. Similarly, another former NYSPUT graduate, T. J. Kajwang, the current member of parliament for the Ruaraka constituency, was also arrested for participating in Odinga's supposedly 'illegal' swearing-in ceremony. Wafula Buke was a key strategist and trusted associate of Odinga during this period.
} 


\section{References}

Adar, K. G. (2000) 'The internal and external contexts of human rights practice in Kenya: Daniel arap Moi's operational code', African Sociological Review 4 (1): 74-97.

Ade Ajayi, J. F. et al. (1996) The African Experience with Higher Education. Athens $\mathrm{OH}$ : Ohio University Press.

Ajulu, R. (2000) 'Thinking through the crisis of democratisation in Kenya: a response to Adar and Murunga', African Sociological Review 4 (2): 133-57.

Amuke, I. (2018) 'Raila Odinga and the comrades', The Elephant, <https://www. theelephant.info/features/2018/03/31/raila-odinga-and-the-comrades $>$, accessed 18 June 2018.

Amutabi, M. (2002) 'Crisis and student protest in universities in Kenya: examining the role of students in national leadership and the democratization process', African Studies Review 45 (2): 157-77.

Amutabi, M. (2003) 'Political interference in the running of education in postindependence Kenya: a critical retrospection', International Journal of Educational Development 23: 127-44.

Balsvik, R. R. (1998) 'Student protest: university and state in Africa 1960-1995', Forum for Development Studies 2: 301-25.

Bjerk, P. (2015) Building a Peaceful Nation: Julius Nyerere and the establishment of sovereignty in Tanzania, 1960-1964. Rochester NY: Boydell and Brewer.

Branch, D. (2011) Kenya: between hope and despair, 1963-2011. New Haven CT: Yale University Press.

Buke, W. (n.d.) 'Back to the trenches'. Unpublished manuscript.

Burgess, G. T. and A. Burton (2010) 'Introduction' in A. Burton and H. ChartonBigot (eds), Generations Past: youth in East African history. Athens OH: Ohio University Press.

Chege, M. (2009) 'The politics of education in Kenyan universities: a call for a paradigm shift', African Studies Review 52 (3): 55-71.

Coe, R. L. (1973) 'Kenya National Youth Service: governmental response to young political activists'. Papers in International Studies: Africa Series. Athens OH: Ohio University.

Comaroff, J. and J. L. Comaroff (2005) 'Reflections on youth: from the past to the postcolony' in A. Honwana and F. De Boeck (eds), Makers and Breakers: children and youth in postcolonial Africa. Trenton NJ and Asmara: Africa World Press.

Cooksey, B., D. Court and B. Makau (1995) 'Education for self-reliance and harambee' in J. Barkan (ed.), Beyond Capitalism vs Socialism in Kenya and Tanzania. Nairobi: East African Educational Publishers.

Court, D. (1980) 'The development ideal in higher education: the experience of Kenya and Tanzania', Higher Education 9 (6): 657-80.

Furley, O. W. and T. Watson (1978) A History of Education in East Africa. New York NY: NOK Publishers.

Hodgkinson, D. and L. Melchiorre (2019) 'Introduction: student activism in an era of decolonization', Africa 89 (S1): S1-S14.

Honwana, A. and F. De Boeck (2005) Makers and Breakers: children and youth in postcolonial Africa. Trenton NJ and Asmara: Africa World Press. 
Hornsby, C. (2012) Kenya: a history since independence. New York NY: I. B. Taurus.

Hyden, G. (1994) 'Party, state and civil society: control versus openness' in J. Barkan (ed.), Beyond Capitalism vs Socialism in Kenya and Tanzania. Nairobi: East African Educational Publishers.

Ivaska, A. (2011) Cultured States: youth, gender and modern style in 1960s Dar es Salaam. New York NY: Duke University Press.

Kamencu, M. (2013) 'Student activism in the University of Nairobi and democratic space, 1970-1992'. Master's thesis, University of Nairobi.

Kiai, M. (1992) Haven of Repression: a report on the University of Nairobi and academic freedom in Kenya. Nairobi: Kenya Human Rights Commission.

Klopp, J. and J. R. Orina (2002) 'University crisis, student activism, and the contemporary struggle for democracy in Kenya', African Studies Review 45 (1): 43-76.

Kuria, A. (1982) 'Lecturer on sedition charge', Daily Nation, 8 June, p. 1.

Kuria, A. (1985) 'Mwandawiro on seven charges', Daily Nation, 15 February, p. 1.

Luescher-Mamashela, T., S. Kiiru, R. Mattes, A. Mwollontallima, N. Ng'ethe and M. Romo (2016) The University and Democratic Citizenship: hothouse or training ground? Wynberg: Centre for Higher Education Transformation (CHET).

Lynch, G. (2011) I Say to You: ethnic politics and the Kalenjin in Kenya. Chicago IL: University of Chicago Press.

Mamdani, M. (2012) Define and Rule: native as political identity. Cambridge MA: Harvard University Press.

McKown, R. E. (1975) 'Kenya university students and politics' in W. Hanna (ed.), University Students and African Politics. New York NY: Africana Publishing Company.

Melchiorre, L. (2018) 'Building nations, making youth: institutional choice, nation-state building and the politics of youth activism in post-colonial Kenya and Tanzania'. PhD thesis, University of Toronto.

Miguna, M. (2012) Peeling Back the Mask: a quest for justice in Kenya. Toronto: Gilgamesh Publishing.

Moi, D. A. (1986) Kenya African Nationalism: nyayo philosophy and principles. New York NY: Macmillan.

Monaville, P. (2012) 'The destruction of the university: violence, political imagination and the student movement in Congo-Zaire, 1969-1971' in S. Christiansen and Z. Scarlett (eds), The Third World in the Global Sixties. New York NY: Berghahn Books.

Mulaki, G., S. W. Kwayara and C. Gicheru (1985) 'Anti-riot police disperse students', Daily Nation, 11 February.

Musyoka, C. and KNA (1982) 'Moi reveals weapons plot', Daily Nation, 7 June, p. 1.

Musyoka, C. and P. Nyamora (1987) 'Varsity students riot over rally', Daily Nation, 16 November, p. 1.

Mutunga, W. and M. Kiai (1996) 'The state of academic freedom in Kenya 19921994' in The State of Academic Freedom in Africa. Dakar: CODESRIA.

Muya, W. (1987) 'Varsity expels 43 students', Daily Nation, 28 November, p. 1.

Muya, W. (1990) 'Students NYS course suspended', Daily Nation, 28 August, p. 32 . 
Mwangi, V. (1987) 'Libya financed students' polls', Daily Nation, 1 December, p. 1.

Mwangi, V. and C. Gicheru (1985) 'Students get new order on uniforms', Daily Nation, 23 March, p. 1.

Mwangola, M. (2007) 'Leaders of tomorrow? The youth and democratization in Kenya' in G. R. Murunga and S. W. Nasong'o (eds), The Struggle for Democracy in Kenya. London: Zed Books.

Nderitu, D. and I. Ndirangu (1982) 'University crackdown', Daily Nation, 11 June, p. 1.

Nderitu, D. and J. Nyamu (1982) ‘Two lecturers picked up', Daily Nation, 9 June, p. 1.

Ndirangu, I. (1985) 'Hunt is on for student inciters', Daily Nation, 14 February, p. 1 .

Ndirangu, I. and G. Njihia (1985) 'Varsity students plan to sue state', Daily Nation, 8 February, p. 1.

Ng'weno, H. (1975) 'National service scheme', The Weekly Review, 14 April, p. 3.

Njau, M (1982) 'Varsity closed over riots', Daily Nation, 8 May, p. 1.

Njau, M., W. Muya and P. Nyamora (1987) 'Riots: senate closes varsity', Daily Nation, 17 November, p. 1, 14.

Nyong'o, P. A. (1989) 'State and society in Kenya: the disintegration of the nationalist coalition and the rise of presidential authoritarianism, 1963-1978', African Affairs 88 (351): 229-51.

Omanga, D. and K. arap Buigutt (2017) 'Marx in campus: print capitalism, nationalism and student activism in the late 1970s Kenya', Journal of East African Studies 11 (4): 571-89.

Ong'iyo, O. and C. Musyoka (1985) 'Students burn NYS uniforms', Daily Nation, 22 March, p. 1.

Osiemo, N. (1985) 'Students file case', The Standard, 8 February, p. 1.

Savage, D. and C. Taylor (1991) 'Academic freedom in Kenya', Canadian Journal of African Studies 25 (2): 308-21.

Scott, J. C. (1998) Seeing Like a State: how certain schemes to improve the human condition have failed. New Haven CT: Yale University Press.

Tamarkin, M. (1978) 'The roots of political stability in Kenya', African Affairs 77 (308): 297-320.

Throup, D. (1987) 'The construction and deconstruction of the Kenyatta state' in M. Schatzberg (ed.), The Political Economy of Kenya. New York NY: Praeger Press.

Throup, D. and C. Hornsby (1998). Multi-party Politics in Kenya. Oxford: James Currey.

Waller, R. (2006) 'Rebellious youth in colonial Africa', Journal of African History 47: 77-92.

Widner, J. (1992) The Rise of the Party-state From 'Harambee!' to 'Nyayo!' Berkeley CA: University of California Press.

Young, C. M. (1981) 'The African university: universalism, development and ethnicity', Comparative Education Review 25 (2): 145-63. 


\begin{abstract}
In May 1984, the Kenyan government of Daniel arap Moi introduced a National Youth Service pre-university training programme (NYSPUT) for prospective university students. The programme was designed to instil discipline in Kenyan university students and inculcate them with a sense of loyalty and commitment to the Moi regime prior to their arrival on campus. This article argues that, in practice, however, the scheme had unintended consequences: it served to alienate student recruits from the ruling party and helped radicalize a small but vocal group of student activists, who, when they arrived on campus, confronted the Moi state with some of its most defiant political challenges of the 1980s. Relying on extensive interviews with former student recruits and archival research, this article highlights the key role that the NYSPUT played in shaping Kenya's young generation of 1980s student activists, who represented one of the most united and militant student movements in the country's history.
\end{abstract}

\title{
Résumé
}

En mai 1984, le gouvernement kenyan de Daniel arap Moi mit en place un programme de formation pré-universitaire dans le cadre du Service national de la jeunesse (NYSPUT) destiné aux futurs étudiants universitaires. Ce programme visait à instiller la discipline aux étudiants universitaires kenyans et à leur inculquer le sens de la loyauté et de l'engagement envers le régime de Moi avant leur arrivée sur le campus universitaire. Or, dans la pratique, l'article suggère que le programme a eu un effet pervers : il a servi à aliéner les nouveaux étudiants du parti au pouvoir et aidé à radicaliser un groupe d'étudiants activistes faible en nombre mais fort en voix qui, lorsqu'ils sont arrivés sur le campus, ont compté parmi ceux qui ont le plus défié la politique du gouvernement Moi dans les années 1980. S'appuyant sur de longs entretiens avec d'anciens nouveaux étudiants et sur des recherches archivistiques, cet article souligne le rôle essentiel qu'a joué le programme NYSPUT dans le façonnage de la jeune génération d'étudiants activistes kenyans des années 1980, qui a représenté l'un des mouvements étudiants les plus unis et les plus militants de l'histoire du pays. 